\title{
Pregnancy and embryo loss rates in non-lactating mares bred in the first or in other estrus cycles during the breeding season
}

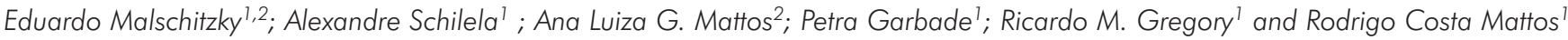

REPROLAB, Universidade Federal do Rio Grande do Sul, Porto Alegre ${ }^{1}$ and ULBRA, Canoas ${ }^{2}$

\begin{abstract}
Summary
The aim of the present study was to compare pregnancy and embryo loss rates in non-lactating mares bred either in the first, or in other estrus cycles during the breeding season. A total of 324 non-lactating mares, 179 of them barren and 145 maiden, were allocated in a stallion management center in Southern Brazil. All the mares were submitted to an artificial photoperiod of 15 hours light/9 hours darkness, either from May 15th on, or later on, from the moment they entered the management center. All the mares have been examined twice a week, from July 15th to July 31 st, in order to determine the estrus phase, being classified, according to the findings, into two groups: group 1 = 1st estrus - mares showing reduced uterine tonus, small sized ovaries or ovaries with irregular follicular activity, lacking evidence of preovulatory follicle and, mainly, of corpus luteum $(C L)$ at ultrasound; group $2=\Delta 2^{\text {nd }}$ estrus - mares presenting $C L$ at examination. The last ones received Prostaglandin on the 5th day after CL identification, or later on, for induction of a new estrus cycle. From August 1st on, all mares in estrus have been examined at maximal intervals of 48 hours, in order to evaluate follicular growth, grade of uterine edema and presence of intra-uterine fluid (IUF). Mares have been bred when a preovulatory follicle and low grade of uterine edema were found. A new examination was performed 36 to 48 hours after breeding to confirm ovulation and to detect IUF. Mares showing IUF were treated by means of uterine flushes and antibiotic infusion and those showing IUF for more than three consecutive days were excluded from the experiment. Barren and maiden mares bred in the 1 st estrus cycle showed significant lower $(p<0,026)$ pregnancy rates in days 12 and 42 in comparison to mares bred during subsequent cycles. Barren mares bred during the 1 st estrus cycle showed higher embryo loss rate $(p=0.048)$ than barren mares bred during other cycles $(20.4 \%$ vs. $8.0 \%)$. Embryo loss rate was not significantly different in maiden mares bred in 1 st or in other estrus $(9.1 \%$ vs. $4.9 \%)$. Grade of uterine edema and presence of IUF during estrus did not differ in barren and maiden mares bred either in the 1st, or in other cycles. However, barren mares bred during the 2nd and other cycles showed higher incidence of IUF $(p=0.040) 36$ to 48 hours after breeding than those bred in the 1 st estrus cycle $(51.7 \%$ vs.27.5\%). Presence of IUF was not significantly different $(p=0.680)$ between maiden mares bred during the 1 st or other cycles $(18,2 \%$ vs. $27.0 \%)$. It was concluded that: (a) during the breeding season the fertility of non-lactating mares is lower in the 1st than in other estrus cycles; (b) that a higher embryo loss rate may be expected in barren mares bred in the 1 st than in other estrus cycles of the breeding season and (c) that the lower fertility rate observed during the 1 st estrus cycle is not related to the incidence of post-breeding endometritis.
\end{abstract}

Keywords: mare, pregnancy rates, embryo loss rates, different estrus cycles

\section{Trächtigkeits- und embryonale Verlustraten bei nicht laktierenden Stuten belegt in der ersten oder in anderen Rossen wäh-} rend der Zuchtsaison

Die vorgestellte Studie vergleicht Trächtigkeits- und embryonale Verlustraten bei nicht laktierenden Stuten, welche entweder in der ersten oder in anderen Rossen während der Zuchtsaison belegt wurden. Eine Gesamtzahl von 324 nicht laktierenden Tieren, davon 145 Maidenstuten und 179 güste Stuten, wurden in ein Hengstmanagementcenter in Südbrasilien überwiesen. Alle Stuten wurden einem künstlichen Beleuchtungsregime mit 15 Stunden Licht und 9 Stunden Dunkelheit, entweder vom 15. Mai oder vom Tag ihrer Einlieferung an, unterzogen. Sie wurden vom 15. bis zum 31. Juli zweimal wöchentlich zur Bestimmung der Zyklusphase untersucht. Entsprechend der Ergebnisse dieser Untersuchungen wurden die Tiere in zwei Gruppen unterteilt: Gruppe 1 = erste Rosse, reduzierter Uterustonus, kleine Ovarien, irreguläre Follikelaktivität, Abwesenheit von präovulatorischen Follikeln oder Gelbkörpern; Gruppe 2 = zweite oder spätere Rosse, Vorhandensein von Gelbkörpern. Die Stuten der Gruppe 2 erhielten zur Induktion eines neuen Zykluses am fünften Tag nach dem Gelbkörpernachweis oder später Prostaglandin. Ab dem 1. August wurden alle rossigen Stuten im Abstand von maximal 48 Stunden untersucht, um Follikelwachstum, Grad des uterinen Ödems und mögliche intrauterine Flüssigkeitsansammlungen zu evaluieren. Eine Belegung erfolgte, wenn ein präovulatorischer Follikel und nur geringgradige Uterusödematisierung vorgefunden wurde. Eine neuerliche Untersuchung wurde 36 bis 48 Stunden nach der Belegung zur Bestätigung der Ovulation und Nachweis möglicher intrauteriner Flüssigkeit durchgeführt. Stuten, welche hierbei durch Ansammlung von intrauteriner Flüssikeit auffielen, wurden mittels Uterusspülungen und Antibiotikainstillation behandelt; hielt der Zustand dennoch für länger als drei zusammenhängende Tage an, wurden die Stuten von der Studie ausgeschlossen. Güste und Maidenstuten belegt in der ersten Rosse zeigten signifikant niedrigere $(p<0,026)$ Trächtigkeitsraten am Tag 12 und 42 post ovulationem als Tiere, welche in nachfolgenden Rossen belegt wurden. Bei güsten Stuten belegt in der ersten Rosse konnten höhere embryonale Verluste $(p=0,048)$ als bei güsten Stuten, welche in anderen Rossen $(20,4 \%$ vs. 8,0 \%) belegt wurden, beobachtet werden. Die embryonalen Verlustraten bei Maidenstuten unterschieden sich nicht signifikant in Abhängigkeit vom Belegungszeitpunkt (erste Rosse $9,1 \%$ vs. andere Rosse 4,9\%). Im Grad des uterinen Ödems und im Nachweis intrauteriner Flüssigkeitsansammlungen während des Östrus unterschieden sich die in verschiedenen Rossen belegten Maidenstuten nicht von den güsten Stuten. Allerdings zeigten in der zweiten oder späteren Rosse belegte güste Stuten ein häufigeres Auftreten von intrauterinen Flüssigkeitsansammlungen 36 bis 48 Stunden nach der Belegung $(p=0,040)$ als solche belegt in der ersten Rosse $(51,7 \%$ vs. $27,5 \%)$; bei Maidenstuten war dieser Unterschied (18,2\% vs. 27,0 \%) nicht signifikant $(p=0,680)$. Zusammenfassend wurde daraus geschlossen, dass (a) die Fertilität von nicht laktierenden Stuten in der ersten 
Rosse der Zuchtsaison niedriger ist als in nachfolgenden Rossen, dass (b) bei güsten Stuten belegt in der ersten Rosse höhere embryonale Verluste erwartet werden können, als bei Belegungen in einer späteren Rosse und dass (c) eine geringere Fertilitätsrate in der ersten Rosse nicht mit dem Vorkommen von nach der Belegung auftretenden Endometritiden zusammenhängt.

Schlüsselwörter: Reproduktion, Stute, Trächtigkeitsraten, embryonale Verlustraten, verschiedene Rossen

\section{Introduction}

Adult female horse usualy shows seasonal poliestric reproductive activity, with a period of ovarian inactivity, called anestrus, occurring in Winter. Between this period and that of ovarian cyclic activity, another period, known as transitional phase, takes place. This phase is characterized for a long period of heat, in which several follicles grow and become athretic before the first ovulation occurs, due to low luteinizing hormon (LH) circulating levels (Ginther 1992). The irregular follicular growth causes a long period of heat, in which the mare can be bred more frequently than in regular cycles (Roser et al. 1997). Environmental factors, specially the increase in light period, are responsible for the higher frequency and amplitude of $\mathrm{GnRH}$ pulses, leading to higher $\mathrm{LH}$ plasma levels. On the other hand, stressing environmental factors may decrease LH levels by means of releasing endogenous inhibiting opioids (Irvine and Alexander 1994).

$\mathrm{LH}$ is responsible for the final oocyte maturation, for ovulation, luteal development and maintenance of corpus luteum (Irvine and Alexander 1994). It has been shown that its wave is smaller in the first estrus cycle of the year, compared with the subsequent cycles, suggesting that the hypothalamichypophyseal axis, in what concerns to $\mathrm{LH}$, is not completely free from inhibitory environmental factors, such as low luminosity, when the first ovulation occurs. Furthermore, a strong positive correlation has been found between $\mathrm{LH}$ and progesterone levels from 5th to 28th pregnancy day (Nett et al. 1979). This reinforces the role of LH on the formation and maintenance of corpus luteum. The early LH surge is also responsible for the follicular secretion of estradiol (Irvine and Alexander 1994).

Hayes et al. (1985), based on the grade of uterine edema evaluated by ultrasound, showed that estrogen average level is lower during the heat preceding the first ovulation, when compared to subsequent ovulations. Estrogen effects on uterine defense mechanisms are well known (Hughes and Loy 1975, Evans et al. 1986); a long period of heat preceding the first breeding could help to improve fluid elimination accumulated during winter anestrus, when the steroid level and the uterine tonus are low, specially in older mares (Irvine 1994).

The aim of the present study was to compare pregnancy and embryo loss rates in non-lactating mares bred either in the first, or in other estrus cycles during the breeding season.

\section{Material and methods}

The group of study was composed of 324 non-lactating mares, 179 of them barren, with ages between 4 and 24 years, and 145 of them maiden, with ages between 3 and 9 years, and 12 proven fertile Thoroughbred stallions. Mares were allocated in a stallion management center in Southern
Brazil. Animals were kept in semi-intensive conditions, in individual boxes during the night and lose in field during the day. All the mares were submitted to an artificial photoperiod of 15 hours light/9 hours darkness, either from May 15th on, or later on, from the moment they entered the management center.

All the mares were examined twice a week, from July 15th to July $31^{\text {st }}$, in order to determine the estrus phase, being classified into two groups, according to the findings:

Group $1-1^{\text {st }}$ estrus cycle

mares showing reduced uterine tonus, small sized ovaries or ovaries with irregular follicular activity, lacking evidence of preovulatory follicle and, mainly, of corpus luteum $(\mathrm{CL})$ at ultrasound;

Group $2-\Delta 2^{\text {nd }}$ estrus cycle mares showing $\mathrm{CL}$ at examination. This group received Prostaglandine 1 on the 5th day after $\mathrm{CL}$ identification, or later on, in order to induce a new cycle.

From August $1^{\text {st }}$ on, all mares in estrus were examined at maximal intervals of 48 hours, in order to evaluate follicular growth, grade of uterine edema and presence of intra-uterine fluid (IUF). The grade of uterine edema was classified in a scale from 1 (non-evidence of edema - diestrus) to 3 (intense uterine edema - estrus).

Mares were bred when a preovulatory follicle ( $>40 \mathrm{~mm}$ ) has been found, in association to a reduced grade of uterine edema. A new examination was performed 36 to 48 hours after breeding to confirm ovulation and to detect IUF. Mares showing IUF were treated by means of, at least, three uterine flushes (2 liters each), followed by antibiotic uterine infusion (5.000.000 IU Penicillin K ${ }^{1}$ or $1.6 \mathrm{~g}$ Gentamicine ${ }^{2}$ ). Mares showing IUF for more than three consecutive days were excluded from the experiment.

Pregnancy was diagnosed with ultrasound, mode B, real time, with a $5 \mathrm{MHz}$ linear transducer ${ }^{3}$. If an embryo vesicle had been detected, control examinations were performed, at least once a week, until the 45th pregnancy day. Twin pregnancies were manually reduced until the 16th day after ovulation. As embryo losses were considered those losses occurring between the day of pregnancy detection and day 42 after ovulation.

The interval of time between the arrival of the mare at the establishment and the ovulation day in the first breeding cycle was called "Adaptation Period". The number of days between August $1^{\text {st }}$ (beginning of the breeding season) and the ovulation day in the first cycle was called "Initial Period".

Pregnancy rates and embryo loss rates were compared using chi-square test. Results were analyzed using Analysis of Variance and Randomizing Test, comparing both groups accor- 
ding to the age, adaptation period, initial period, number of mounts/heat and number of cycles/pregnancy. To accept null hypothesis, the probability criteria were superior to the preestablished alpha $(a=0,05)$. Software MULTIV 2000 was used (Pillar 2000).

\section{Results}

Pregnancy and embryo death rates in barren and in maiden mares, bred either in the $1^{\text {st }}$ or in other ( $\Delta 2$ nd) estrus cycle during the breeding season are shown in Tables 1 and 2:

Tab 1 Pregnancy and embryo death (ED) rates in Thoroughbred maiden mares bred either in the 1st, or in other ( 2 nd ) cycles during the breeding season.

Anzahl von Trächtigkeiten und embryonalen Verlusten bei Vollblut-Maidenstuten, die entweder während des ersten Zyklus der Zuchtsaison oder der darauffolgenden Zyklen gedeckt wurden. (Different characters $(a, b)$ in columns indicate significant difference $\left(c^{2}=4.93 ; p=0.026\right)$. Different characters $(c, d)$ in columns indicate significant difference $\left(c^{2}=5.55 ; p=0.018\right)$. Same character (e) in columns indicates non-significant difference $\left(c^{2}=0.82 ; p=0.365\right)$

\begin{tabular}{|c|c|c|c|c|c|c|}
\hline \multirow[t]{2}{*}{ Group } & \multirow[t]{2}{*}{$n$} & \multicolumn{2}{|c|}{$\begin{array}{l}\text { Pregnancy in } \\
\text { day } 12\end{array}$} & \multicolumn{2}{|c|}{$\begin{array}{l}\text { Pregnancy in } \\
\text { day } 42\end{array}$} & \multirow{2}{*}{$\begin{array}{c}\text { ED } \\
\%\end{array}$} \\
\hline & & $\mathrm{N}$ & $\%$ & $\mathrm{~N}$ & $\%$ & \\
\hline $1^{\text {st }}$ estrus & 69 & 44 & $63.7^{\circ}$ & 40 & $57.9^{c}$ & $9.1^{\mathrm{e}}$ \\
\hline$\geq 2^{\text {nd }}$ estrus & 76 & 61 & $80.3^{b}$ & 58 & $76.3^{d}$ & $4.9^{\circ}$ \\
\hline
\end{tabular}

Tab 2 Pregnancy and embryo death (ED) rates in Thoroughbred barren mares bred either in the 1st, or in other (2nd) cycles during the breeding season.

Anzahl von Trächtigkeiten und embryonalen Verlusten bei güsten Vollblutstuten, die entweder während des ersten Zyklus der Zuchtsaison oder der darauffolgenden Zyklen gedeckt wurden.

Different characters $(a, b)$ in columns indicate significant difference ( $\left.c^{2}=5.28 ; p=0.021\right)$. Different characters $(c, d)$ in columns indicate significant difference ( $\left.c^{2}=8.88 ; p=0.003\right)$. Different characters $(e, f)$ in columns indicates non-significant difference ( $\left.c^{2}=3.90 ; p=0.048\right)$

\begin{tabular}{ccccccc}
\hline Group & $\mathbf{n}$ & \multicolumn{2}{c}{$\begin{array}{c}\text { Pregnancy in } \\
\text { day } 12\end{array}$} & \multicolumn{2}{c}{$\begin{array}{c}\text { Pregnancy in } \\
\text { day } 42\end{array}$} & ED. \\
\cline { 2 - 5 } & & $\mathrm{N}$ & $\%$ & $\mathrm{~N}$ & $\%$ & $\%$ \\
\hline $1^{1^{\text {st }} \text { estrus }}$ & 77 & 44 & $57.1^{\mathrm{a}}$ & 35 & $45.4^{\mathrm{c}}$ & $20.4^{\mathrm{e}}$ \\
$\geq 2^{\text {nd }}$ estrus & 102 & 75 & $73.5^{\mathrm{b}}$ & 69 & $67.6^{\mathrm{d}}$ & $8.0^{\mathrm{f}}$ \\
\hline
\end{tabular}

Barren and maiden mares bred in the $1^{\text {st }}$ estrus cycle showed significant lower $(p<0.026)$ pregnancy rates in days 12 and 42 , if compared to mares bred during other cycles. Barren mares bred during the $1^{\text {st }}$ estrus cycle showed greater embryo death rate $(p=0.048)$ than barren mares bred during other cycles $(20.4 \%$ vs. $8.0 \%)$. Maiden mares did not show significantly different embryo loss rates between both groups $(9.1 \%$ vs. $4.9 \%$ ) (Tab. 1 and 2 ).

The average age, the number of mates/heat, the number of cycles/pregnancy, the adaptation period and the initial period of maiden and barren mares, bred either in the $1^{\text {st }}$, or in other cycles, are shown in Table 3.

There was no difference $(p>0.05)$ between average ages of maiden and barren mares bred either in the $1^{\text {st }}$, or in other cycles during the breeding season. Maiden mares bred during other cycles had a number of cycles/pregnancy significantly lower $(p=0.049)$ than those bred during the first estrus cycle. Among barren mares, the number of
Tab 3 Average age, mates/heat, cycles/pregnancy, adaptation period and initial period of maiden and barren mares bred either in the 1st, or in other (2nd) cycles during the breeding season. Mittleres Alter, Anzahl der Bedeckungen pro Rosse, Anzahl der Zyklen bis zur Trächtigkeit, Länge der Adaptationszeit (= Zeit zwischen Ankunft auf der Station und erster Ovulation), Länger der Initialperiode (= Zeit zwischen Beginn der Zuchtsaison, 1. August, und erster Ovulation) bei maiden und güsten Stuten, die entweder während des ersten Zyklus der Zuchtsaison oder der darauffolgenden Zyklen gedeckt wurden.

Same characters $(a, b)$ in row indicate non-significant difference $(p=0.47 ; p=0.59$, respectively). Different characters $(c, d)$ in row indicate significant difference $(p=0.002)$. Different characters (e, $f))$ in row indicate significant difference $(p=0.001)$. Same character $(g))$ in row indicates non-significant difference $(p=0.738)$ Different characters $(h, i))$ in row indicate significant difference $(p=0.001)$. Same character (i) ) in row indicates non-significant difference $(p=0.18)$. Different characters $(k, I))$ in row indicate non-significant difference $(p=0.0001)$. Different characters $(m$, $n))$ in row indicate non-significant difference $(p=0.049)$. Different characters $(o, p))$ in row indicate non-significant difference $(p=0.01)$.

\begin{tabular}{ccccc}
\hline Average & \multicolumn{2}{c}{ Maiden } & \multicolumn{2}{c}{ Barren } \\
\cline { 2 - 5 } & $1^{\text {st }}$ estrus & $\geq 2^{\text {nd }}$ estrus & $1^{\text {st }}$ estrus & $\geq 2^{\text {nd }}$ estrus \\
\hline Age (years) & $4.7^{\mathrm{a}}$ & $4.9^{\mathrm{a}}$ & $11.2^{\mathrm{b}}$ & $10.9^{\mathrm{b}}$ \\
Adaptation period & $40.3^{\mathrm{c}}$ & $64.1^{\mathrm{d}}$ & $54.8^{\mathrm{e}}$ & $94.1^{\mathrm{f}}$ \\
(days) & & & & \\
Initial period & $24.3^{\mathrm{g}}$ & $23.6^{\mathrm{a}}$ & $28.8^{\mathrm{h}}$ & $20.6^{\mathrm{i}}$ \\
Mates/heat & $1.5^{\mathrm{i}}$ & $1.3^{\mathrm{i}}$ & $1.9^{\mathrm{k}}$ & $1.3^{\mathrm{i}}$ \\
Cycles/pregnancy & $1.5^{\mathrm{m}}$ & $1.4^{\mathrm{n}}$ & $2.0^{\circ}$ & $1.6^{\mathrm{p}}$ \\
\hline
\end{tabular}

cycles/pregnancy was also lower $(p=0.01)$ in mares bred during other cycles. Barren mares bred in the $1^{\text {st }}$ estrus underwent a significantly greater number of mates/cycle than those bred in other cycles. Maiden and barren mares bred in the $2^{\text {nd }}$ cycle, or later on, had a longer adaptation period. The average interval between the beginning of the season and breeding was shorter in barren mares bred in $2^{\text {nd }}$ and subsequent cycles $(p=0.001)$. The maximal grade of uterine edema during heat in different experimental groups of maiden and barren mares is shown in Tables 4 and 5 Concerning to the grade of uterine edema during heat, no significant difference was found between mares bred in $1^{\text {st }}$ or in $2^{\text {nd }}$ and subsequent cycles, either in maiden $(p=0.231)$, or in barren $(p=0.383)$ mares.

Tab 4 Maximal grade of uterine edema in Thoroughbred maiden mares bred either in the $1^{\text {st }}$, or in other $\left(\Delta 2^{\text {nd }}\right)$ cycles during the breeding season

Maximaler Grad des Uterusödems bei Vollblut-Maidenstuten, die entweder während des ersten Zyklus der Zuchtsaison oder der darauffolgenden Zyklen gedeckt wurden.

Same character (a) in columns indicates non-significant difference $\left(c^{2}=1.432 ; p=0.231\right)$

\begin{tabular}{cccccc}
\hline Group & $\mathbf{n}$ & \multicolumn{2}{c}{ Edema 1.5 - 2 } & \multicolumn{2}{c}{ Edema 2.5 - 3 } \\
\cline { 3 - 6 } & & $\mathrm{N}$ & $\%$ & $\mathrm{~N}$ & $\%$ \\
\hline $1^{\text {st }}$ estrus & 33 & 14 & $42.4^{\mathrm{a}}$ & 19 & $57.6^{\mathrm{a}}$ \\
$\geq 2^{\text {nd }}$ estrus & 37 & 21 & $56.7^{\mathrm{a}}$ & 16 & $43.3^{\mathrm{a}}$ \\
\hline
\end{tabular}

Tab 5 Maximal grade of uterine edema in Thoroughbred barren mares bred either in the $1^{\text {st }}$, or in other $\left(\Delta 2^{\text {nd }}\right)$ cycles during the breeding season

Maximaler Grad des Uterusödems bei güsten Vollblutstuten, die entweder während des ersten Zyklus der Zuchtsaison oder der darauffolgenden Zyklen gedeckt wurden.

Same character (a) in columns indicates non-significant difference $\left(c^{2}=1.15 ; p=0.283\right)$

\begin{tabular}{cccccc}
\hline Group & $\mathrm{n}$ & \multicolumn{2}{c}{ Edema $1.5-2$} & \multicolumn{2}{c}{ Edema 2.5 - 3 } \\
\cline { 3 - 6 } & & $\mathrm{N}$ & $\%$ & $\mathrm{~N}$ & $\%$ \\
\hline $1^{\text {st }}$ estrus & 40 & 16 & $40^{a}$ & 24 & $60^{a}$ \\
$\geq 2^{\text {nd }}$ estrus & 29 & 8 & $27.6^{a}$ & 21 & $72.4^{a}$ \\
\hline
\end{tabular}


The frequency of intra-uterine fluid accumulation during heat and 36-48 hours after breeding in maiden and barren mares bred in the $1^{\text {st }}$ or in other estrus cycles during the breeding season is shown in Tables 6 and 7 .

Tab 6 Frequency of intra-uterine fluid accumulation in Thoroughbred maiden mares bred either in the $1^{\text {st }}$, or in other $\left(\Delta 2^{\text {nd }}\right)$ cycles during the breeding season

Häufigkeit des Auftretens einer intrauterinen Flüssigkeitsakkumulation bei Vollblut-Maidenstuten, die entweder während des ersten Zyklus der Zuchtsaison oder der darauffolgenden Zyklen gedeck wurden.

Same character (a) in columns indicates non-significant difference $\left(c^{2}=0.03 ; p=0.985\right)$. Same character $(b)$ in columns indicates non-significant difference ( $c^{2}=0.771 ; p=0.680$ ).

\begin{tabular}{cccccc}
\hline Group & $\mathbf{n}$ & \multicolumn{2}{c}{ Fluid heat } & \multicolumn{2}{c}{$\begin{array}{c}\text { Fluid } 36-48 \mathrm{~h} \text { after } \\
\text { breeding }\end{array}$} \\
\cline { 2 - 6 } & & $\mathrm{N}$ & $\%$ & $\mathrm{~N}$ & $\%$ \\
\hline $1^{\text {st }}$ ovulation & 33 & 4 & $12.1^{\circ}$ & 6 & $18.2^{\mathrm{b}}$ \\
$\geq 2^{\text {nd }}$ ovulation & 37 & 4 & $10.8^{\circ}$ & 10 & $27^{\mathrm{b}}$ \\
\hline
\end{tabular}

Tab 7 Frequency of intra-uterine fluid accumulation in Thoroughbred maiden mares bred either in the $1^{\text {st }}$, or in other $\left(2^{\text {nd }}\right)$ cycles during the breeding season

Häufigkeit des Auftretens einer intrauterinen Flüssigkeitsakkumulation bei güsten Vollblutstuten, die entweder während des ersten Zyklus der Zuchtsaison oder der darauffolgenden Zyklen gedeck wurden.

Same character (a) in columns indicates non-significant difference $\left(c^{2}=0.03 ; p=0.985\right)$. Same character $(b)$ in columns indicates non-significant difference ( $c^{2}=0.771 ; p=0.680$ )

\begin{tabular}{cccccc}
\hline Group & $\mathrm{n}$ & \multicolumn{2}{c}{ Fluid heat } & \multicolumn{2}{c}{$\begin{array}{c}\text { Fluid } 36-\mathbf{4 8} \mathrm{h} \text { after } \\
\text { breeding }\end{array}$} \\
\cline { 3 - 6 } & & $\mathrm{N}$ & $\%$ & $\mathrm{~N}$ & $\%$ \\
\hline $1^{\text {st }}$ estrus & 40 & 7 & $17.5^{\mathrm{a}}$ & 11 & $27.5^{\mathrm{b}}$ \\
$\geq 2^{\text {nd }}$ estrus & 29 & 11 & $37.9^{\circ}$ & 15 & $51.7^{\mathrm{c}}$ \\
\hline
\end{tabular}

A higher incidence $(p=0.040)$ of IUF was found 36 to 48 hours after breeding in barren mares bred during 2 nd and subsequent cycles than in those bred during the $1^{\text {st }}$ estrus cycle (51.7\% vs.27.5\%). That did not happen to maiden mares, in which no significant difference $(p=0.680)$ was found concerning to the presence of IUF after breeding between mares bred during the $1^{\text {st }}$ or in other cycles $(18.2 \%$ vs. $27.0 \%$ ). Presence of IUF during heat was not different between mares bred either in the $1^{\text {st }}$, or in other cycles.

\section{Discussion}

Data presented in this work showed that the pregnancy rate of maiden mares bred in the $1^{\text {st }}$ estrus cycle during the breeding season was significantly lower $(63.7 \%)$ than that of the mares bred in other estrus cycles (80.3\%), results similar to those observed previously by Mattos et al. (1997 and 1999). However, no significant difference $(p>0.05)$ regarding the $E L$ rate was observed between the first and other estrus cycles, being the EL rates in agreement with those found by Ginther (1992).

The poor fertility rate found in the $1^{\text {st }}$ estrus cycle may be attributed to lower LH levels, which may result from seasonal or environmental changes. $\mathrm{LH}$ levels are lower in the $1^{\text {st }}$ than in other estrus cycle of the season (Ginther 1992), suggesting that, at the moment of the $1^{\text {st }}$ ovulation, the effects of the increasing photoperiod have not been totally reached yet, and that the hypothalamus-hypophyseal axis is not totally free from the inhibition provoked by the pineal gland. This fact may be confirmed by the decreased number of days of artificial photoperiod to which mares bred in the $1^{\text {st }}$ estrus were submitted (44.2), in comparison to mares bred in other cycles (64.1 days).

Mares included in the present study were kept in a commercial establishment, being exposed to environmental changes, such as adverse climate, and needing to readapt to life in group and to hierarchic status. All these factors are potentially capable to influencing the GnRH synthesis and, consequently, the LH level, by means of the inhibition generated by b-endorphins (Irvine and Alexander 1994). Mares bred in the $2^{\text {nd }}$ estrus, or later on, may have been benefited by a longer period of environmental adaptation, in comparison to those mares bred in the $1^{\text {st }}$ estrus.

Barren mares showed different pregnancy rates when bred in the $1 \mathrm{st}(57.1 \%)$ or in other estrus (73.5\%). In addition, barren mares bred in the $1^{\text {st }}$ estrus showed higher $(p=0.048)$ embryo loss rate $(20.4 \%)$ than those bred from the $2^{\text {nd }}$ estrus on $(8 \%)$.

A great number of subfertile, aged mares, with history of endometritis, could be found among barren mares. In this way, embryo losses occurring from the $2^{\text {nd }}$ day after ovulation on could be associated to uterine and oviductal pathology (Ball et al. 1989, Ginther 1992).

Despite the higher incidence of persistent post-breeding endometritis (fluid accumulation 36 - 48 hours after breeding) seen in mares bred in the 2 nd estrus cycle, the embryo loss rate was higher in mares bred in the $1^{\text {st }}$ estrus. This result suggests that cases of persistent post-breeding endometritis are possibly related rather to individual conditions, than to the breeding cycle. On the other hand, despite the higher frequency of post-breeding uterine fluid accumulation, better pregnancy rates and lower embryo loss rates found in mares bred from the $2^{\text {nd }}$ estrus on may reflect their higher ability in responding to post-breeding treatments in these cycles, when compared to the $1^{\text {st }}$ cycle. This is probably due to oxytocin injection, which promotes an endometrial response mediated by a PgF2a secreting factor (Nikolakopoulus et al. 2000). A progesterone priming seems to be necessary to promote endometrial secretion of prostaglandin (Ginther 1992). A short period of high progesterone concentration, which occurred in mares bred in the $2^{\text {nd }}$ and other cycles, could have improved this mechanism.

Barren mares were also exposed to environmental conditions impairing reproductive activity and showed too a shorter adaptation period. Thus, the hypothesis that the results found in mares bred in the $1^{\text {st }}$ estrus cycle are due to low $\mathrm{LH}$ levels seems to apply also to this group.

No significant difference was found in the number of maiden and barren mares showing maximal or intermediate grade of uterine edema in the $1^{\text {st }}$ and in other estrus cycles. This result differs from those reported by Hayes et al. (1985), who observed a smaller number of mares with maximal and intermediary grade of uterine edema during the $1^{\text {st }}$ estrus. A positive correlation between the grade of edema and uterine fluid accumulation was observed by Reilas et al. (1997). The reason for not finding difference in the grade of edema in 
distinct estrus cycles cannot be explained based on the results obtained.

Mares bred after the $1^{\text {st }}$ estrus showed a longer adaptation period and were bred earlier in the season. This is probably due to the moment in which the artificial photoperiod began (May 15th). It was shown that mares submitted to artificial photoperiods of 14.5 to 16 hours light/day ovulate, in average, 70 days after the beginning of the stimulus (Palmer and Guillaume 1989). Onset of photoperiod in May allows the first estrus cycle to occur before the official beginning of the breeding season. So, the second estrus cycle takes place earlier and breeding in this cycle offers better pregnancy results.

It was concluded (a) that during the breeding season the fertility of non-lactating mares is lower in the $1^{\text {st }}$ than in other estrus cycles; (b) that a higher embryo loss rate may be expected in barren mares bred in the $1^{\text {st }}$ than in other estrus cycles during the breeding season and (c) that the lower fertility rate observed during the $1^{\text {st }}$ estrus cycle is not related to the incidence of post-breeding endometritis.

\section{Manufacturers}

1 Aricilina- Ariston Indústria Química e Farmacêutica Ltda, Brazil

2 Gentaflex- Eurofarma Laboratórios, Ltda, Brazil

3 Aloka SS-210DX - Aloka Inc., Japão

\section{Literature}

Ball B. A., T. V. Little, J. A. Weber and G. L. Woods (1989): Survival of day-4 embryos from young, normal mares and aged subfertile mares after transfer to normal recipient mares. J. Reprod. Fert. 85, 187-194

Evans M. J., J. M. Hamer, L. M. Gason, C. S. Graham, A. C. Asbury and C. H. G. Irvine (1986): Clearence of Bacteria and Non-Antigenic Markers Following Intra-Uterine Inoculation Into Maiden Mares: Effect of Steroid Hormone Environment. Theriogenology $26,37-50$

Ginther O. J. (1992): Reproductive Biology of the Mare: Basics and Applied Aspects. Cross Plains, Equiservices, 146-170, 499-558
Hayes K. E. N., R. A. Pierson, S. T. Scraba and O. J. Ginther (1985): Effects of estrous cycle and season on ultrasonic uterine anatomy in mares. Theriogenology 24, 465-477

Hughes J. P. and R. G. Loy (1975): The Relation of Infection and Infertility in the Mare and Stallion. Equine Vet. J. 7, 155-159

Irvine C. H. G. (1994): Hormonal Causes of Functional Disorders of Reproduction in the Non-pregnant Mare: Their Diagnosis and Treatment. ARS Veterinária 10, 46-55

Irvine C. H. G. and S. L. Alexander (1994): The role of environmental factors in reproduction in the mare. ARS Veterinária 10, 33-41

Mattos R. C., E. Malschitzky and R. M. Gregory (1997): Effect of different postbreeding treatments on fertility of Thoroughbred mares. Pferdeheilkunde 13, 512-515

Mattos R. C., L.bS. Meirelles, E. Malschitzky, A. P. Neves, A. L. G. Mattos, M. J. Vieira, A. Keller, A. K. Hött and R. M. Gregory (1999): Oxytocin, plasma containing leukocytes or combination of both as tretment of postbreeding endometritis. Pferdeheilkunde $15,584-587$

Nett T. M., B. W. Pickett and E. L. Squires (1979): Effect of equimate $(\mathrm{ICl}-81008)$ on levels of luteinizing hormone, follicle-stimulating hormone and progesterone during the oestrus cycle of the mare. J.Anim.Sci. 48, 69-75

Nikolakopoulus E., H. Kindahl and E. D. Watson (2000): Oxytocin and PGF2a Release in mares resistant and susceptible to persistent mating-induced endometritis. Journal of Reproduction and Fertility. 56(suppl.), 363-372

Palmer E. and D. Guillaume (1989): Control mechanisms of the seasonal ovarian activity of the mare. Anais do IX Congresso Brasileiro de Reprodução Animal. Belo Horizonte, 21 - 33

Pillar V. D. (2000): Multiv - Software para análise multivariada, auto-reamostragem boodstrap e testes de aleatorização. Porto Alegre, Departamento de Ecologia, UFRGS

Reilas T., T. Katila, O. Makela, M. Huhtinen and E. Koskinen (1997): Intrauterine fluid accumulation in oestrus mares. Acta Vet Scand. $38,69-78$

Roser J. F., D. E. Valcheck, B. L. Lasley, I. K. M. Liu, G. Kojusner and $K$. Taya (1997): Minimizing the incidence of endometritis by predicting the first ovulation of the year. Pferdeheilkunde 13, 539

Prof. Dr. Rodrigo Costa Mattos

Reprolab. Dept. of Animal Med.

Faculdade de Veterinaria UFRGS

Av. Bento Goncalves 9090

91540-000 Porto Alegre, Brazil

rcmattos@vortex.ufrgs.br 